\title{
1. Supporting the transition from unemployment to self-employment - a comparative analysis of governmental support programs across Europe
}

Melvin Haas and Peter Vogel

\section{INTRODUCTION}

Governments around the world are facing increasing pressure to reduce unemployment. A deficit of 50 million jobs as compared to the situation before the 2008 financial crisis prevails (ILO, 2002). This not only represents a significant amount of unused economic potential but also threatens to undermine the social stability of entire societies through a marginalization of large groups of people from the working population. One mechanism to help reduce unemployment is to support those who want to become self-employed. For this purpose, several active labor market programs (ALMPs) have been developed across Europe, providing support to those seeking to start a business after a period of unemployment. Despite constituting a relatively small portion of national active labor market expenses (1-6 percent of ALMP spending; OECD, 2000), firms established by the previously unemployed make up a large proportion of all new firms as indicated by the 30 percent in Sweden (Statistics Sweden, 1998), and more than 25 percent in France (Désiage, Duhautois, and Redor, 2010). The political and economic importance of these programs has led to an increased scholarly attention over the past years (Benus, 1994; Block and Sandner, 2006; Corral, Isusi, and Stack, 2006; Bosma et al., 2008; Caliendo and Kritikos, 2009; Block and Wagner, 2010) and it is likely that their political importance will further rise due to ongoing labor market instabilities (ILO, 2002).

Despite the enhanced awareness of these programs that have been widely adopted in a number of countries across Europe, most prior research has restricted its scope to analyzing only one specific country, rather than 
engaging in an international comparative study. A few notable, however outdated, exceptions have employed an internal lens to compare alternative policy schemes and share experiences - both positive and negativeacross borders (Staber and Bögenhold, 1993; Meager, 1996; OECD, 2000). While some countries have gained considerable knowledge about how to structure their policy initiatives based on experiences from past revisions, other countries have only recently introduced such policy schemes. An international comparative analysis that is able to offer an encompassing yet also detailed an overview of existing self-employment support programs could therefore serve as a basis for policymakers trying to improve existing - and implementing new-support programs.

The purpose of this chapter is to provide an overview and analysis of such policy schemes from several European countries. The selection of countries seeks to reflect the diversity with regards to economic importance, political orientation, history and culture, as well as the variety of program structures that have been implemented. It includes the large economies of France, Germany and Great Britain; their smaller, centrally located neighbors of Austria, Belgium, the Netherlands and Switzerland; the northern, Scandinavian country of Sweden; the eastern European countries of Poland and the Czech Republic; and the southern European countries of Greece and Spain.

Similarities and differences between the programs are investigated in order to contribute to increasing their effectiveness (for example, pointing out suitable policy instruments) and their efficiency (for example, by employing limited public funds with maximum positive impact). The program structure, the eligibility requirements, the different forms of financial support, as well as the availability of nonfinancial business support services are presented. Subsequently, a number of differing policy approaches are identified and analyzed in greater detail. The chapter concludes with a discussion of our findings, including suggestions for policymakers and employment agencies that are responsible for the implementation and operation of such programs.

\section{EVOLUTION OF SELF-EMPLOYMENT SUPPORT PROGRAMS}

Over the past three decades, many European countries have established dedicated programs designed to help unemployed individuals transition into self-employment. Research about the nature and processes of firm creation by formerly unemployed individuals has identified two fundamental reasons advocating the implementation of such policy schemes, namely 
(1) market failures in the allocation of capital and entrepreneurial talent, and (2) a number of positive economic - and externalities - social resulting from the creation of new businesses (ILO, 2002; Nolan, 2003).

Market failures can be addressed by governmental interventions to improve access to entrepreneurial resources, such as financing and business support services. Formerly unemployed entrepreneurs often lack financial resources to set up and grow their businesses and may be refused bank loans (typically due to their lack of income, because the amounts are too small, or because of missing collateral). For these reasons, formerly unemployed firm founders are experiencing disproportionate difficulties in starting a business. Without self-employment support programs, they are thus more likely to be establishing under-resourced businesses with poor survival chances from the onset (ILO, 2002). Support programs can additionally help mitigate the lack of entrepreneurial skills that concerns some of these people through the provision of different types of business support services and entrepreneurial training.

Positive economic and social effects resulting from the creation of new businesses represent the second reason promoting the implementation of self-employment support schemes. Supporting unemployed people in their transition to self-employment is supposed to relieve the welfare system, promote efficient markets and ultimately lead to economic stability and economic growth (Storey, 1994; Fritsch, 2008). Furthermore, the programs stimulate the labor market as many of the supported firms have been shown to create additional jobs (Parker 1994; Nolan, 2003; Dencker, Gruber, and Shah, 2009a). Even in case the self-employment experience finally proves unsuccessful, prior studies have reported a favorable impact on the chances of becoming re-employed (for example, Kellard and Middleton, 1998; OECD, 2000; Caliendo and Künn, 2011). In contrast to other active labor market programs - such as vocational training or job creation through established companies' schemes - empirical evidence on the efficiency and effectiveness of such policy schemes is still scarce, yet mainly indicates positive results. However, as the majority of prior studies have focused on a single country, including Germany (Caliendo and Künn, 2011; Dencker, Gruber, and Shah, 2009a; Dencker, Gruber, and Shah, 2009b), Poland and Hungary (O’Leary, 1999), Romania (Rodríguez-Planas, 2008), Spain (Cueto and Mato, 2006), Sweden (Carling and Gustafson, 1999), and the United Kingdom (UK) (Meager, Bates, and Cowling, 2003), these studies can not be generalized and do not allow for an international comparison.

Policy schemes designed to support formerly unemployed individuals in their transition to self-employment have evolved from fairly simple structures through a number of revisions until their current, more refined state of development. These modifications have typically occurred based on 
experiences made within the respective nation, yet international coordination attempts are gaining more importance in parallel with the European Union integration efforts throughout the last decade. While each country has its own program development history, three stages of maturity can be differentiated. These evolutionary stages of development will be detailed in the following paragraphs in order to provide a better understanding of the origins of the current generation of public policy support schemes discussed in this chapter.

\section{Early Policy-development Initiatives}

The development of the earliest programs took place as a response to the increasing rates of unemployment in the 1970s, particularly within the larger OECD economies. France launched their "Aide au chômeur créant ou reprenant une enterprise" (Assistance to those starting a business out of unemployment) program (ACCRE) in 1977, pioneering the concept of a one-time, lump sum payment as a financial contribution equal to the respective unemployment benefit allocation of the applicant. Germany's "Überbrückungsgeld" (bridging allowance) initiative was introduced in 1986 to cover entrepreneurs' subsistence during the start-up phase. At the time, the self-employment contributions consisted of the respective unemployment allowance plus an additional social security insurance contribution for the duration of up to six months. Other examples for these "early-experimenters" include the UK, which introduced their "business startup scheme" in 1983, and Spain with the "Prestaciones por desempleo Capitalización" (Unemployment Capitalization Benefit) in 1985. These early initiatives were all based on a rather simple structure with the main focus being the financial contribution.

\section{Universal Adoption and Expansion of the Policy}

Rising levels of unemployment in the beginning of the 1990s amplified the pressure on policymakers to identify those ALMPs that had the capability of reversing this trend. As a result, policies designed to support the creation of new businesses by the unemployed were gaining momentum in a number of national initiatives during this period (OECD, 1992). Several smaller countries such as Belgium (program introduced in 1992), the Netherlands (1996), Austria (1998) and Switzerland (1998) subsequently adopted the programs that the pioneering countries had created. In France, the initially devised program was changed by legislators in 1987 , both revoking the originally granted legal right to the contribution and also requiring a basic economic feasibility assessment from its applicants. 
In 1993, Sweden reviewed their previously created policy scheme, removing a major obstacle, suddenly making the program accessible to a wider audience, resulting in a surge of participants shortly after being launched (Carling and Gustafson, 1999). Due to the policy initiative, an evidently large, latent demand for opportunities to become self-employed suddenly became feasible. Subsequent evaluation of the program has been largely positive (Carling and Gustafson, 1999). Similarly, Germany revised their "Bridging Allowance" policy in 1994, which resulted in a considerable increase in the number of new firms created. This policy scheme consequently became established as a promising instrument within the existing national ALMP landscape. ${ }^{1}$ The Czech Republic established their self-employment support program as early as 1989, however, it consisted primarily of an indirect backing through a self-employment-friendly tax system. In subsequent years, the initial policy was supplemented by the facilitated access to bank loans. Starting in 2004, additional forms of support including direct financial contributions were introduced using capital provided by the EU Structural Funds (Veverková, 2012). Likewise, Poland (2004) and Greece (2008) have given more political attention to their support schemes to help unemployed people start businesses. During this stage, many countries additionally began administering dedicated programs restricted to certain demographic groups such as for women, younger people and older generations that might otherwise have difficulties re-entering the job market. Additionally, some programs are specifically directed at disadvantaged regions or target only certain subsets of new firms such as social businesses. This stage is thus characterized by an increase in complexity and diversity of the programs.

\section{Continued Refinement and Recent Developments of the Policy Schemes}

Resulting from their increased popularity and visibility, several countries went through additional revisions of their policy schemes based not only on their own past experiences, but also shaped by political debates and societal trends. As a result, the policy schemes have sometimes been altered repeatedly. For example, in France, the initially drafted loan was transformed in 2001 into a grant, only to be transformed back to a loan in 2004. Since 2009, an interest-free loan is available in addition to a partial exoneration from a number of social charges such as health insurance and a companionship-program lasting for three years designed to support those in transition to self-employment through the provision of various business support services. In addition to the existing "Überbrückungsgeld" (bridging allowance) program, Germany launched a policy program termed "Existenzgründungszuschuss" (also known as 
"Ich-AG," "Me-Corporation") in 2003 in order to better cater to those unemployed for extended periods. The total number of supported founders in the country increased to roughly one million people in the following years (IAB, 2007). Although these two programs were replaced by the "Gründungszuschuss" (start-up grant) in 2006, several studies appraised the scheme's effectiveness (for example, Baumgartner and Caliendo, 2008). Furthermore, the survival - and employment-growth rates of previously unemployed founders have been found to be largely comparable to those of companies created by founders without previous unemployment (Pfeiffer and Reize, 2000), the participant income was found to be significantly higher than that of non-participants, and the support schemes were furthermore regarded as comparatively cost-effective labor market policies (IAB, 2007). The new start-up grant offered an extension of the duration for financial support of up to nine months, but simultaneously increased the eligibility requirements for the proposed business concept. In 2012, budget restrictions rendered the previously practiced, comprehensive evaluation of the proposed business idea unfeasible, altering the nature of support from being a legal entitlement to a merely discretionary offer made to those deemed well-prepared. The self-employment support programs in the UK underwent a number of revisions in the 1990s (Duggan, 1998) indicating only limited effectiveness (Storey, 1994), specifically for formerly unemployed individuals (Metcalf, 1998). Current revisions of the program in the UK are also more targeted towards specific groups, such as the "Start-up Loans" program, launched in 2012, dedicated to promoting youth entrepreneurship.

On the one hand, these examples demonstrate how the current stage of development is characterized by an increased professionalism with regards to the administration and implementation of the public policy programs. Many current reforms are rooted in scientific evaluations and a number of countries have established dedicated labor market research institutions charged with the task of monitoring and controlling the effectiveness and efficiency of the national policies. On the other hand, today's popularity and visibility makes the programs increasingly the subject of political discussions, and as a consequence, policies are sometimes repeatedly altered depending on the current political climate and the country's economic situation.

Over the last decades, international bodies such as the OECD or the European Social Fund have begun to recognize the benefits of - and demands for - these types of policy schemes. As a result, coordination efforts in Europe are shifting away from predominantly domestic initiatives towards trans-national coordination efforts, such as the formation of the "European Employment Strategy" (European Commission, 1997) and 
the "OECD Employment Outlook" (OECD, 2000). In recent years, governmental agencies responsible for these policy schemes have organized international conferences aiming at facilitating the exchange of best practices among researchers and practitioners. Moreover, the current "Europe 2020 Strategy" contains entrepreneurship as a key policy priority, not just with regards to economic growth and as an instrument for addressing youth unemployment, but also in relation to the creation of employment in general following the global recession (European Commission, 2010).

While the motivation behind these policy schemes and the evolution of the programs has been illustrated in this section, it also has become apparent that the large diversity of approaches cannot be readily analyzed without the prior identification of meaningful dimensions of comparison. The following section thus identifies a list of criteria facilitating a structured comparative analysis of the current programs in Europe. Existing policy differences are subsequently analyzed based on these dimensions, leading to the examination of three contrasting policy approaches of supporting formerly unemployed individuals in becoming self-employed.

\section{OVERVIEW OF CURRENT SELF-EMPLOYMENT SUPPORT PROGRAMS}

In order to derive meaningful criteria of differentiation between the respective policy initiatives, an overview of the approaches and objectives of the current generation of policy initiatives in selected European countries is given. Following this overview, the program structure, the eligibility criteria for participation, the provision of financial support and the availability of business support services are discussed in more detail. In order to facilitate the design of policies in this realm, we also provide an overview of the key policy dimensions.

Table 1.1 details the programs currently implemented in Austria, Belgium, the Czech Republic, France, Germany, Greece, the Netherlands, Poland, Spain, Sweden, Switzerland, and the UK. As revealed in the introduction, these countries have been selected in order to reflect the cultural, economic and geographic variety in Europe as well as to show the diversity of existing programs. The policy in each country is described by the program name, the governmental agency responsible for its implementation and the date of the initial program (column 1), the program's objectives as well as the forms of aid that are being offered (column 2), as well as the eligibility criteria, the admission procedure, the presence of a potential fallback-solution and requirements regarding the repayment of funds, if applicable (column 3). 


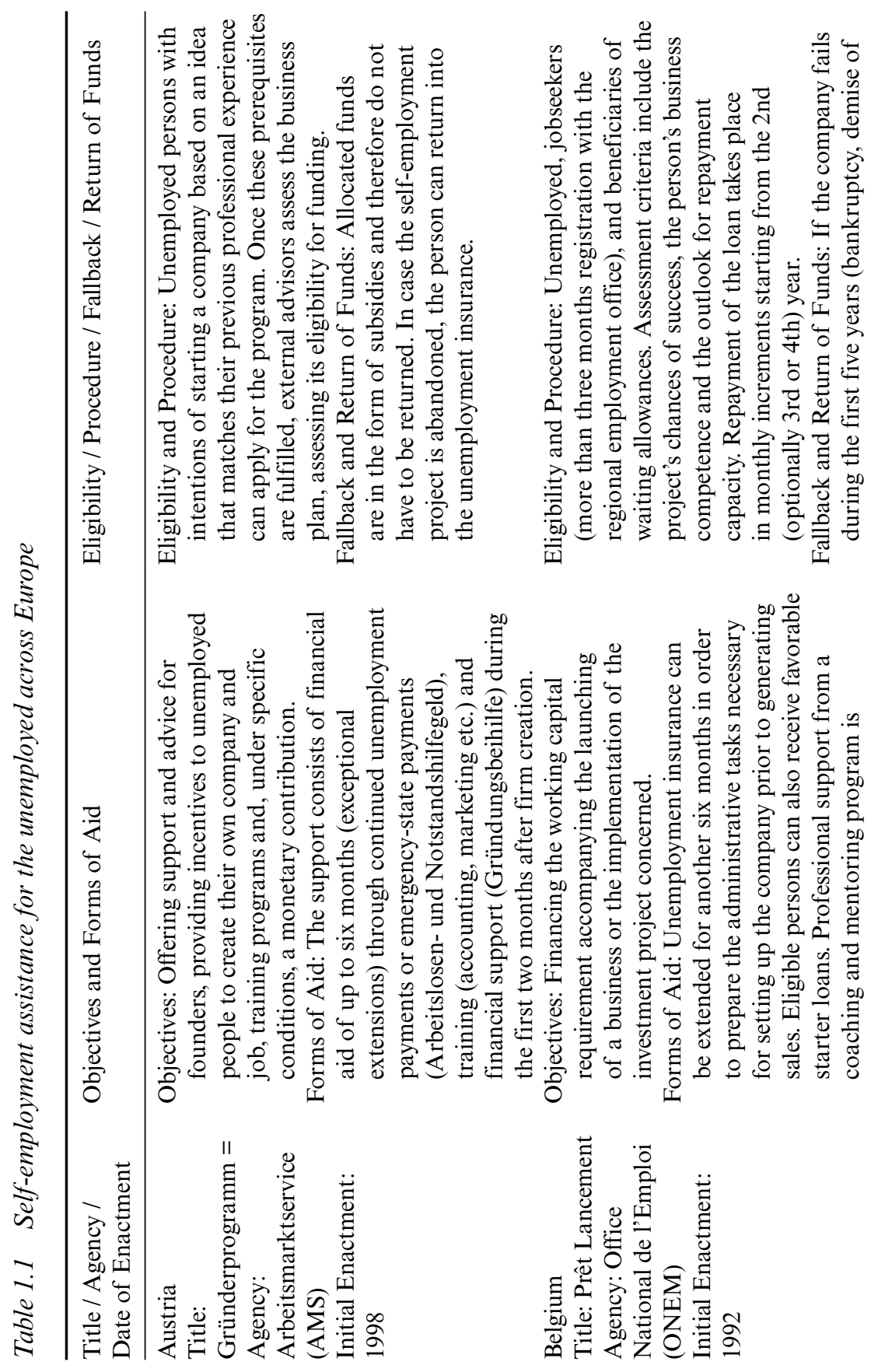




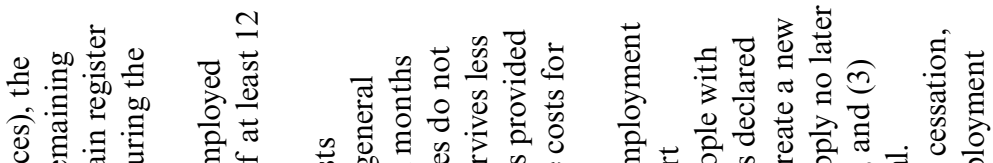

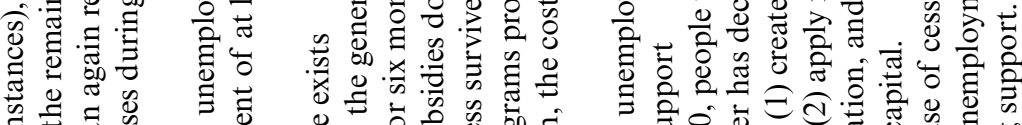

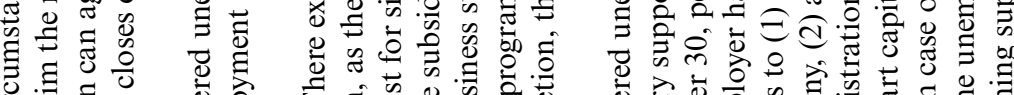

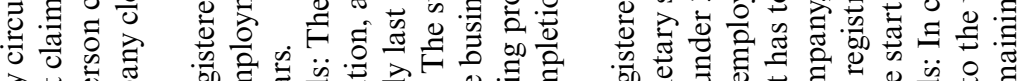

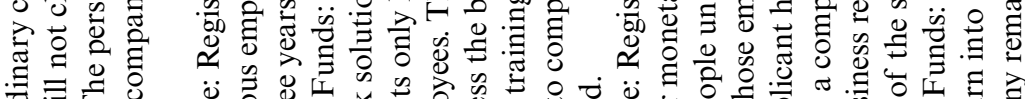

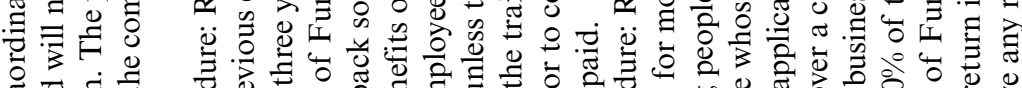
\%

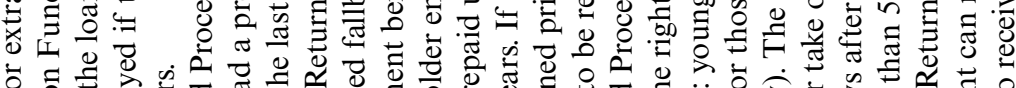

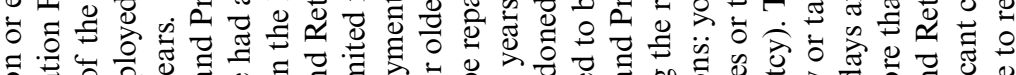

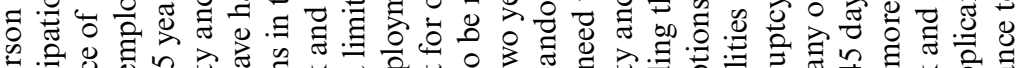

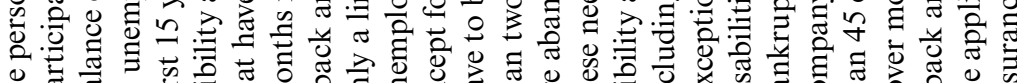

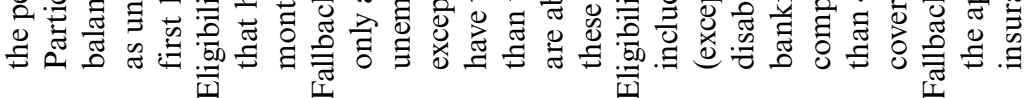
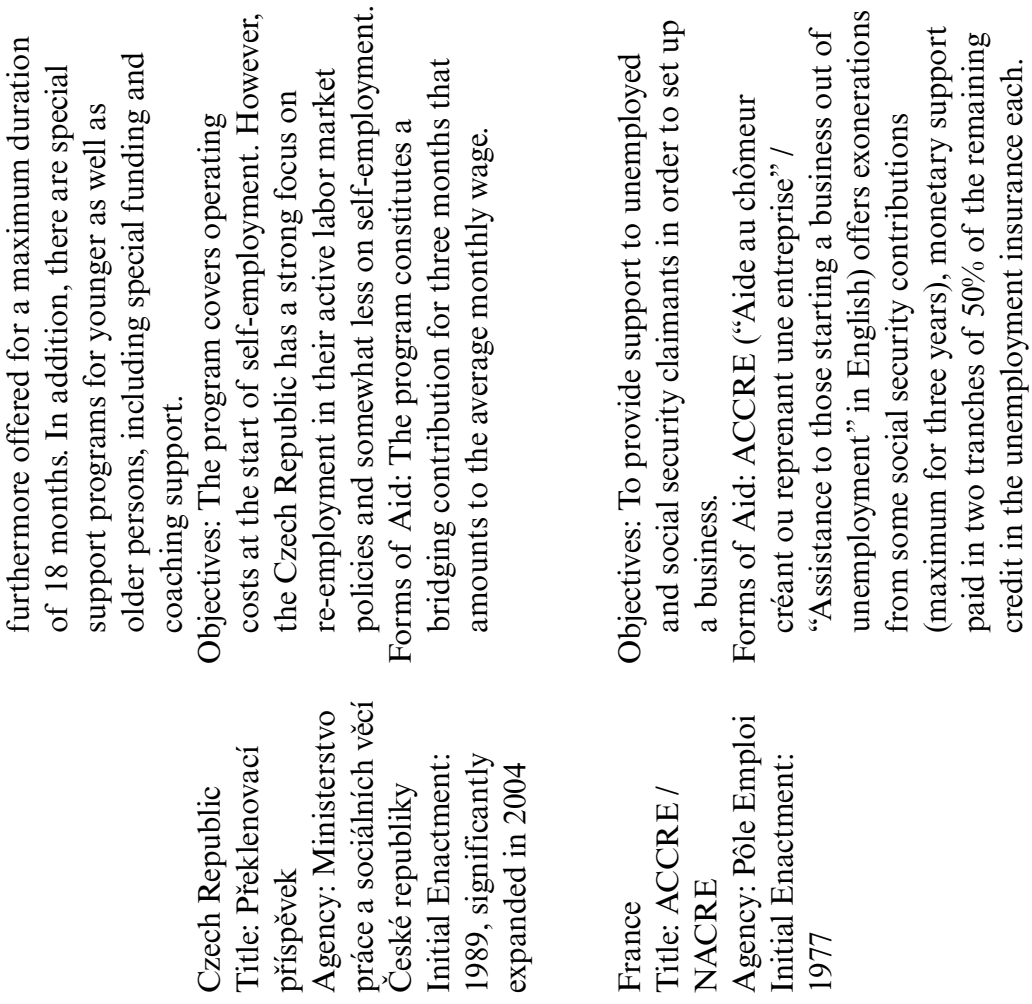


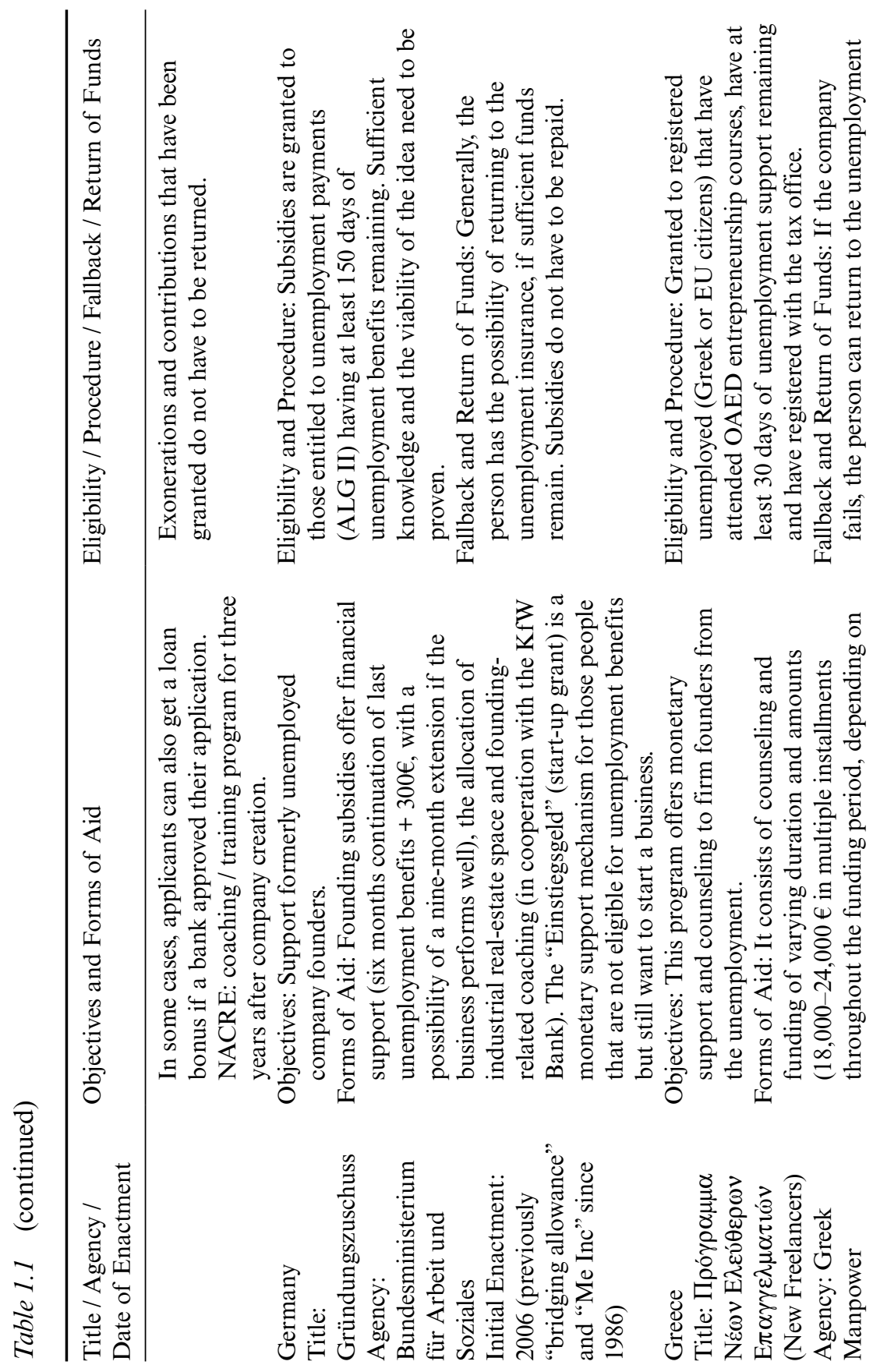




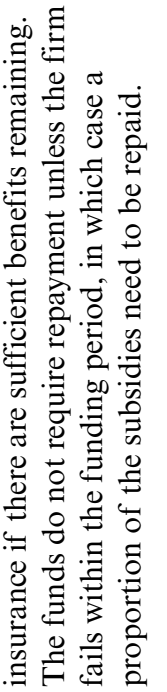
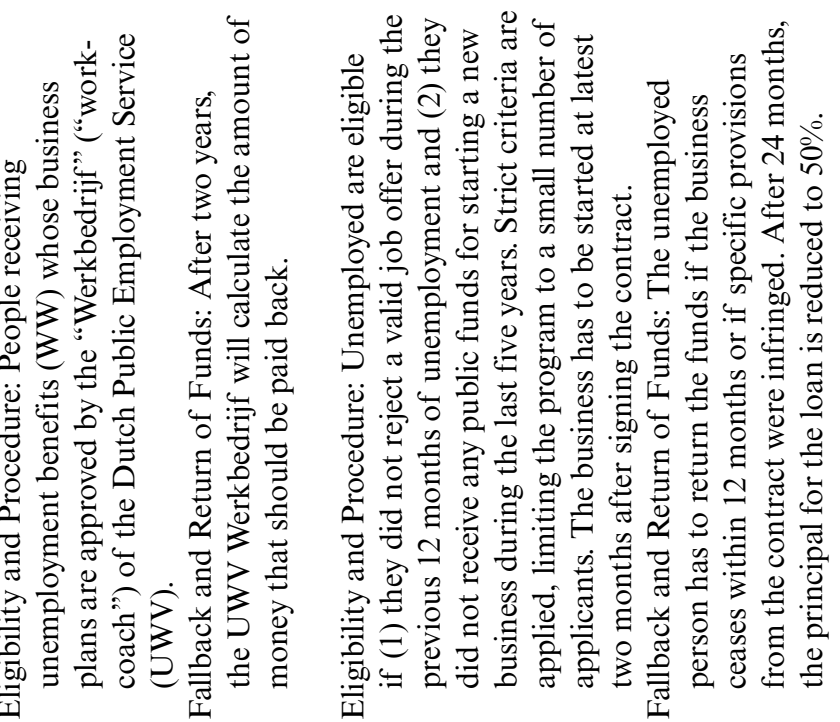

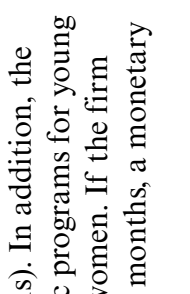

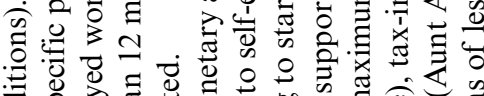

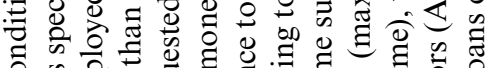

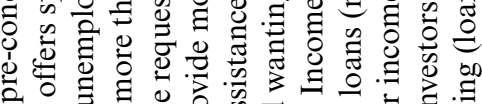

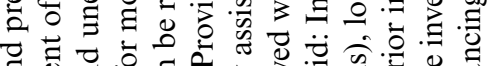

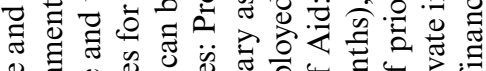

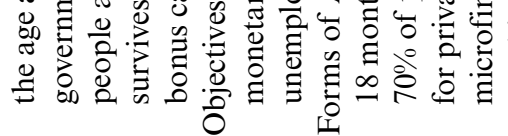

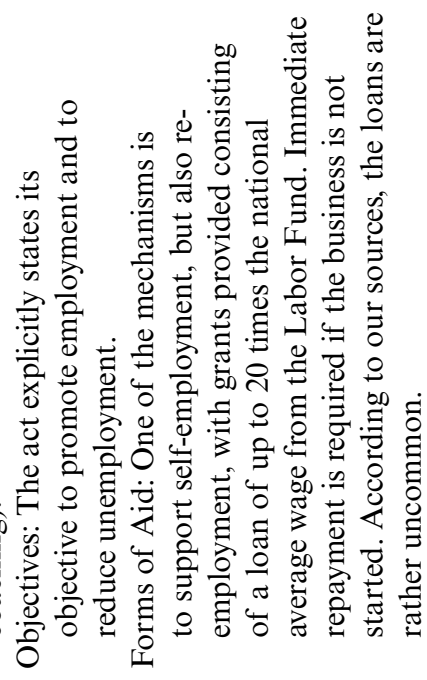

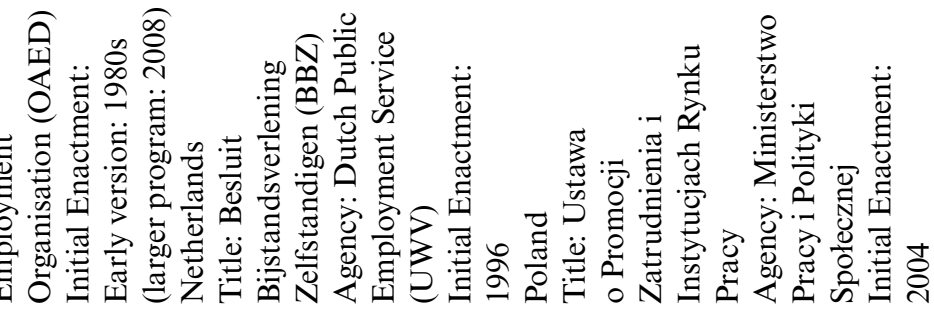




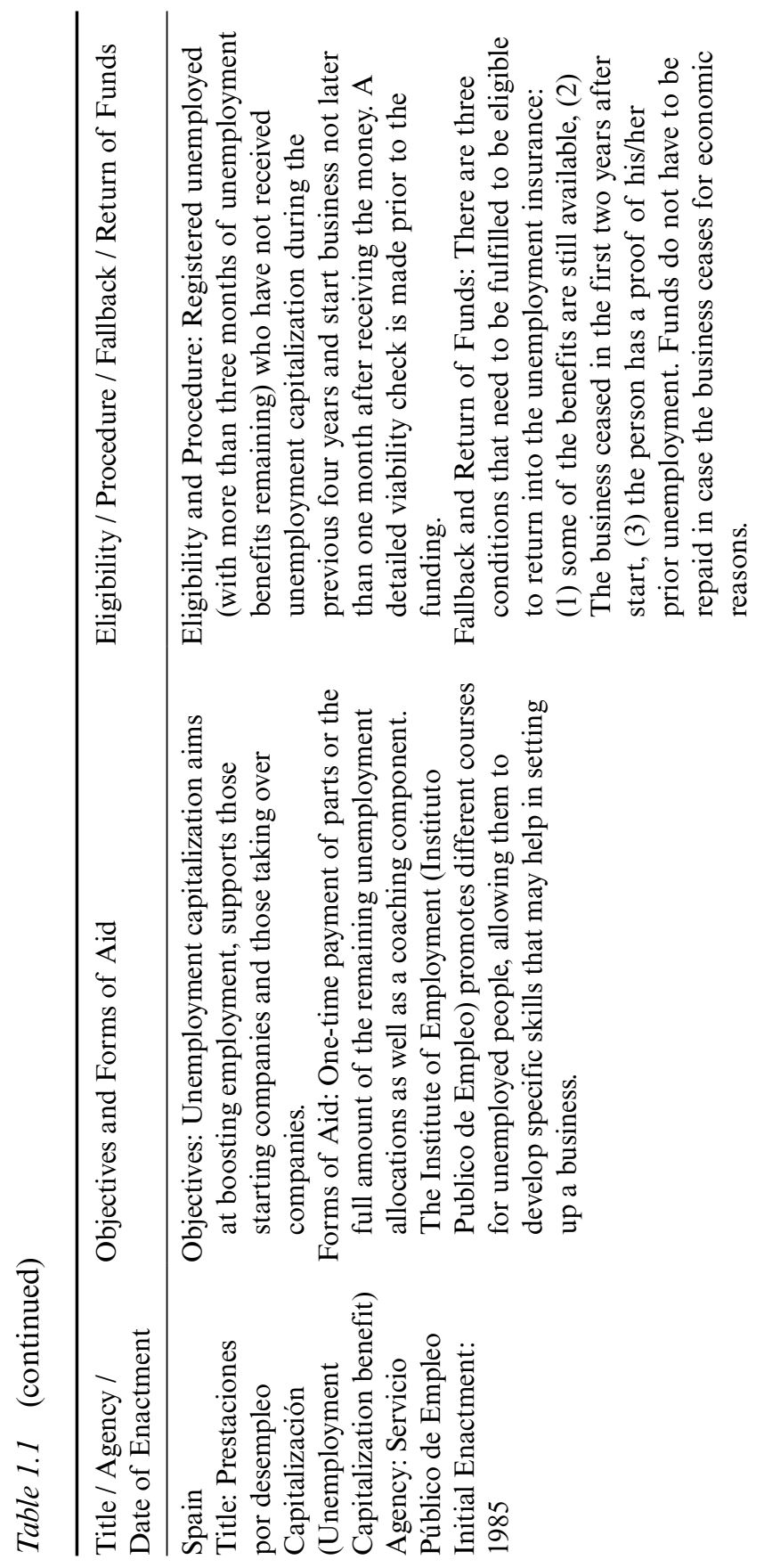

\section{4}




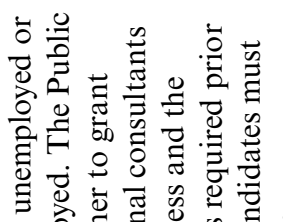

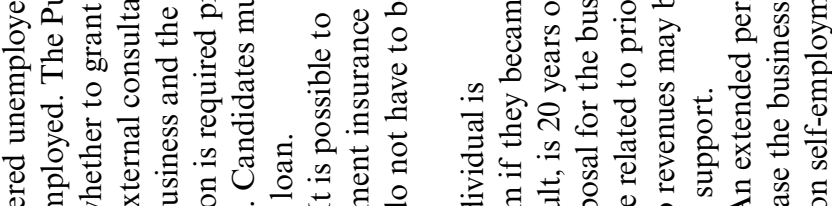

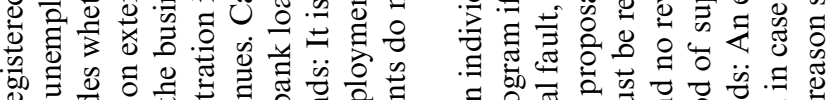

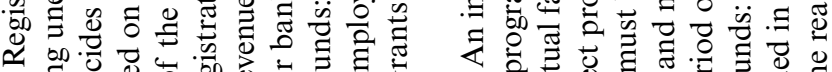

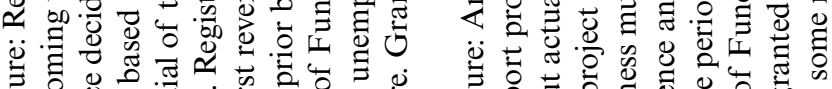

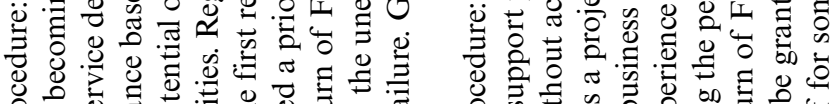

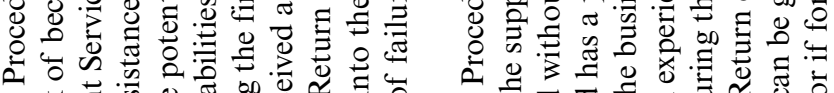

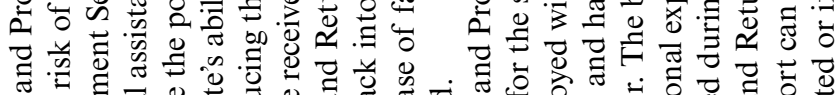

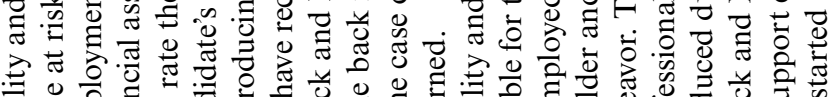

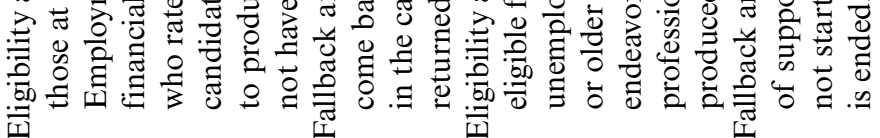

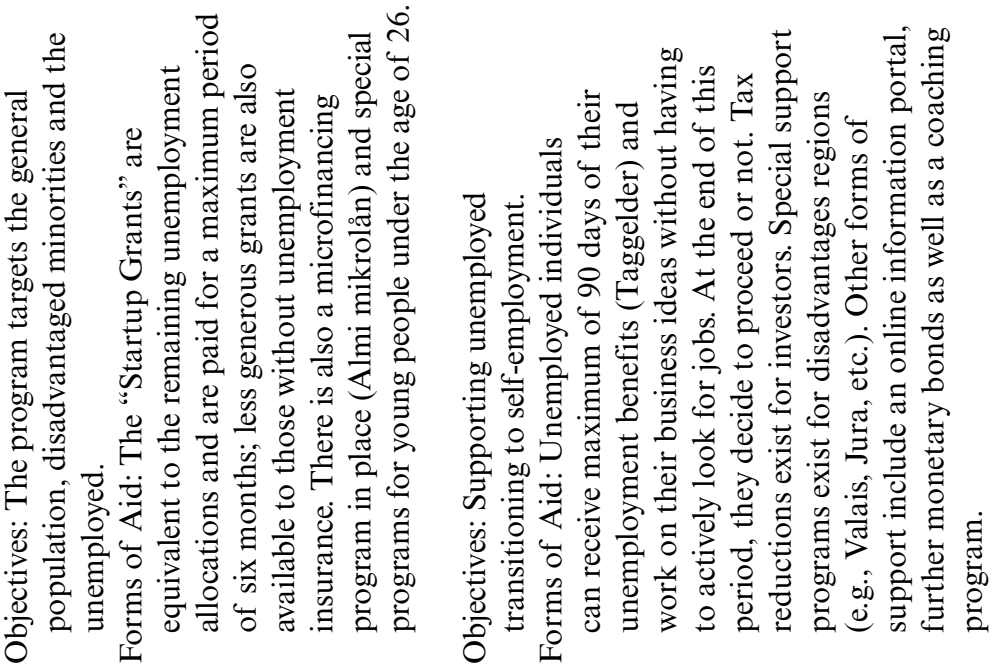

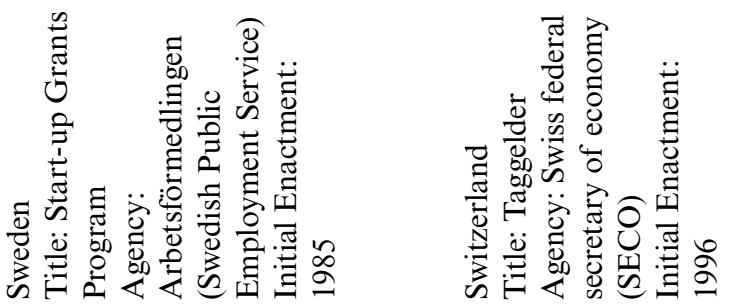




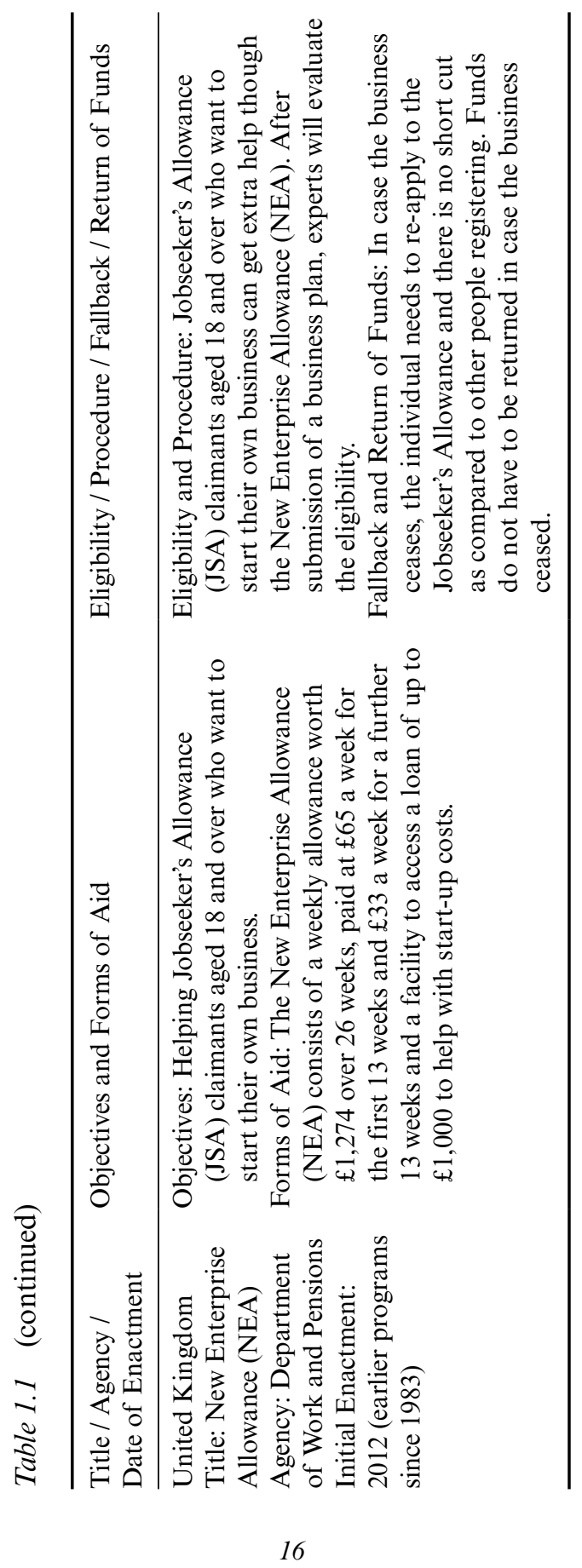




\section{Program Structures}

Differing political landscapes, economic conditions, as well as distinct strategic goals of the various national ALMP instruments have led to several structural differences between the support initiatives. In particular, these programs differ along two main dimensions: (1) whether the programs are administered by centralized or decentralized entities; and (2) whether the initiatives are fully dedicated to those transitioning into self-employment out of unemployment, or whether the participants are channeled into generic support programs also open to firm founders without a prior unemployment experience.

\section{Centralized versus decentralized structure}

As Table 1.1 shows, there is heterogeneity with regards to whether the support programs are centrally-or de-centrally-organized. While the majority of countries in this study offer financial subsidies through a nationwide, centralized support program (for example, Germany-see case study below), other countries feature a range of more decentralized programs (for example, UK). However, due to a large variety of regional programs, the UK underwent a major consolidation effort in 2009 within their Business Support Simplification Programme (BSSP) to reduce the more than 3000 existing programs to less than 100, thus equally shifting towards a more centralized policy administration structure.

Case Study, Germany: Hierarchical Organization of Program Administration The organizational structure for the administration of the German publicpolicy landscape revolves around the "Zentrale der Bundesagentur für Arbeit," a statutory body that acts as the central managing institution for all labormarket related statement of affairs currently in action as defined by the legislative system. These headquarters are well connected to other public institutions concerned with the implementation of policy instruments, as well as to an in-house research and intelligence department for internal controlling purposes. As direct subordinates to the central office, ten regional units across the country govern the implementation of labor-market policies at the intermediate level. These entities coordinate their duties of implementing national policies with other regional initiatives as well as with regional politics. The regional centers furthermore act as a link to the roughly 175 employment agencies ("Agentur für Arbeit") and 600 branch offices ("Geschäftsstellen") throughout the country that are responsible for operationally implementing the strategies defined at the higher levels within their local areas. (Bundesagentur für Arbeit, 2012)

\section{Specific versus general self-employment promotion programs}

While most countries have established dedicated programs to help unemployed individuals transition into self-employment (for example, 
Austria, France, Germany, Spain and Switzerland), others are less focused on this group and combine those starting businesses out of unemployment into generic self-employment support initiatives that are open to anyone interested in starting a firm (for example, in Sweden, Poland and the Czech Republic). Specialized support programs to financially assist unemployed individuals aim at offsetting disadvantages they face with regards to accessing capital, as compared to founders without an unemployment background. We are unaware of any international studies comparing dedicated to generic programs in terms of effectiveness or efficiency.

\section{Program Eligibility and Admission Criteria}

Another key dimension differentiating the national policy schemes represents the eligibility requirements and admission criteria, thus limiting the program's access to a pre-defined group of individuals. This dimension directly reflects the country's strategy of following a more inclusive (for example, Belgium, France, the Netherlands and Sweden), or a more selective (for example, Austria, Germany, Greece, Spain and Switzerland) active labor market strategy. Furthermore, while the general framework of the programs is being defined on a national level, regional actors are responsible for the implementation and execution, partially resulting in a significant variance not only across countries, but also between different regions within the same country. While the majority of countries studied in this chapter have established formal viability checks of new business concepts (1), subjective assessments often play a significant role in determining who is admitted into a program (2). In the following, these two key practices related to the program eligibility and admission criteria are discussed in greater detail.

\section{Viability-check of new business concepts}

Today, the majority of the national programs require the unemployed to provide a business plan when applying for financial support. In order to be eligible for the financial contribution, the proposal typically needs to be assessed and approved by a qualified institution. This trend has likely been fueled by past experiences from overly permissive policy schemes (for example, "Existenzgründungszuschuss" program in Germany), which lead to increased cases of abuse. Some people enrolled in the program for continued monetary support shortly before losing eligibility for unemployment benefits, while others registered as unemployed just to receive the monetary support while starting a company they would likely have started even without the contribution (the "free-rider" phenomenon). 
While permissive programs have the advantage of allowing many people to discover whether self-employment is a viable career path for them, excessively elevated restrictions on the other hand limit the support to people who have increased chances of success, potentially constraining other positive externalities resulting from self-employment. The profound impact of this parameter will be discussed in greater detail in "An Examination of Contrasting Policy Approaches."

\section{The influence of subjective assessments}

Although the eligibility requirements for receiving the support are typically stated in the form of legal decrees referring to clearly defined factors such as a minimum or maximum length of unemployment or the applicant's age, a subjective assessment through the employees of the regional employment agencies is a common practice. In Germany for example, local program coordinators are given authority to decide who is eligible for starting a business and who is denied the financial support. In Switzerland, the cantonal authorities are given autonomy about how strictly the admittance criteria for their policy scheme are applied. As a result, the policy implementations may differ significantly between regions. Comparable project proposals accepted in one region may thus be rejected somewhere else. Although a detailed analysis of such regional differences is beyond the scope of this chapter, it is likely that similar discrepancies exist in countries other than the ones just mentioned.

\section{Practices Related to the Provision of Financial Support}

Capital constraints represent a major barrier for becoming self-employed (for example, Blanchflower and Oswald, 1990). Having access to adequate amounts of financial capital helps founders respond to adverse circumstances, overcome liquidity constraints and influence external stakeholders' perception of the new venture (Shane, 2003). While some basic financial investment is required to start any type of business, the amount varies strongly depending on the type of business opportunity exploited by the founder. Evidence from prior research suggests that unemployed individuals are more likely to become self-employed in manual-and labor-intensive-businesses with a low capital investment (Kellard and Middleton, 1998), likely in part due to financial constraints.

This reality is reflected in the structure of all investigated programs as they offer at least some basic financial support to help bridge the funding gap before the founder can draw a steady income from the new business. However, the specific conditions differ widely across the countries studied in this chapter. In the following, three central factors differentiating the 
examined programs are discussed, namely: (1) whether the financial support is provided in the form of a grant or as a loan; (2) whether it is paid as a single, lump sum payment or as regularly recurring allowances; and (3) whether there exists a fallback solution for the program participant in case the self-employment project is abandoned.

\section{Grants versus loans}

Monetary support is provided in different forms within the analyzed countries. Although there is a general trend of offering grants (funds that are distributed by one party to a recipient that do not have to be repaid) from the unemployment insurances (for example, Austria, Czech Republic, France, Germany, Greece, Spain, Sweden, Switzerland and the UK), some countries have implemented loan schemes that require repayment (for example, Belgium and the Netherlands, as well as France through its NACRE program). In one case, the repayment is only required if the business ceases to operate within a certain timeframe (Poland).

\section{Single payment versus recurring payments}

The above-described monetary support is either provided as a single, lump sum payment (Poland and Spain), or through recurring monthly payments (Austria, Belgium, Czech Republic, France, Germany, Greece, Netherlands, Sweden and Switzerland) or weekly (UK) allowances. Nascent self-employed often need to cover up-front investments, which can vary in magnitude depending on the industry and the activity. The possibility of receiving subsidies in form of a single, lump sum payment can be helpful to cover such expenses. Yet, in order to cover the cost of living, recurring payments (similar to the reception of a regular salary) seem to be advantageous.

\section{Provision of a fallback solution}

A fallback solution allows the participants to re-enter the national welfare system in case the self-employment activity is abandoned, for example due to economic reasons. Offering a fallback solution into the general welfare system in case the business remains unsuccessful appears to be a wellreceived practice. While all countries in this section have some sort of fallback scenario, the specific approaches are different. Some countries offer general fallback solutions with the only criteria being the availability of remaining individual allocations in the unemployment insurance scheme (for example, Austria, France, Germany and Switzerland). Other countries have fallback solutions that are linked to specific requirements such as how long the firm needs to be operating and the mode of failure (for example, the Czech Republic and Poland). 


\section{Nonfinancial Business Support Services}

In addition to an appropriate level of funding, the founder's prior knowledge and professional experience have been shown to influence the long-term success of a new business concept (for example, Shane, 2003; Dencker, Gruber, and Shah, 2009a). Research suggests that nonfinancial business support services can positively influence the success of formerly unemployed firm founders through two central mechanisms.

First, instead of imposing strict eligibility criteria that exclude insufficiently refined business concepts, evidence suggests that supporting individuals to improve unrefined business concepts can potentially increase the supply of promising business concepts (Guérin and Vallat, 2000; Nolan, 2003; Jakobsen and Ellegaard, 2012). Second, once a refined business concept has been developed, there is ample evidence that the establishment and growth of the new businesses can be positively influenced through the provision of appropriate business support services (for example, Brüderl and Preisendörfer, 1998; Sheikh et al., 2002).

While coaching and training programs have long been a central element of the active labor market programs implemented in many countries, initiatives designed to support individuals transitioning into self-employment through the provision for education and business support services represent a comparatively new element of these systems. As a result, the available nonfinancial support varies widely across regions and is often restricted to metropolitan areas; those located in more rural areas are thus occasionally disadvantaged.

However, the educational, nonfinancial component of the governmental support schemes is regarded as being one of their most valued aspects (Kellard and Middleton, 1998). Scientific studies that have been conducted on this matter indicate generally positive outcomes of the self-employed assistance components (OECD, 2000; Martin and Grubb, 2001; Van Es and Van Vuuren, 2011). Even in case the self-employment experience ultimately proves unsuccessful, positive spillover effects with regards to reemployment chances have been discovered (Kellard and Middleton, 1998; OECD, 2000). The comparison of the business support services conducted for this chapter revealed a number of differences with regards to (1) the types of business support available to the program participants; (2) the encouragement of participation in these offerings; and (3) the provision of support through government_-or private-sector-organizations.

\section{Type of business support service}

The evidence we collected shows that the business support services that are relevant to firms founded by the unemployed can be divided into 
three main types: Professional training initiatives offer vocational or technical training typically aimed at individuals seeking to work in skill and labor-intensive professions; general education programs focus on the transfer of theoretical knowledge in a classroom or lecture hall setting, while personalized coaching and consulting support is targeted at individuals in need of advice regarding specific topics arising during the creation of their businesses. Analogous distinctions between the different forms of business support services have been made in the past (for example, Sheikh et al., 2002), yet with a broader focus on micro, small and sole proprietor businesses in general. Table 1.2 provides an overview of the key types of nonfinancial support available to formerly unemployed founders.

Most countries have offerings related to all three types of business support, yet the respective programs receive differing degrees of emphasis and their availability can vary widely not just across different countries, but also across different regions within the same country. Belgium can be seen as an example of a country putting special emphasis on professional training as a viable path to help formerly unemployed individuals transition into self-employment, sporting several institutions with high national visibility (for example, SYNTRA, IFAPME, EFPME). The Czech Republic similarly puts strong emphasis on this type of nonfinancial support within their national ALMP. A focus on providing general education can be observed within the "public university" ("Volkshochschule"; VHS) concept in Germany, but similar institutions can also be found in Austria, the Scandinavian countries, and others. Despite its relatively high costs, some countries such as France explicitly focus on the consulting/ coaching components within their unemployment support policies. In this case, the business support is integrated within the national policy scheme and participants are supported for a maximum duration of up to three years. As each type of business support service is important for a specific type of business, it is still unknown to date which approach is the most cost-effective from a governmental perspective.

\section{Mandatory versus voluntary participation}

Participation in the nonfinancial support offerings is typically voluntary; however an exception to this rule could be identified in Slovakia, a country outside of our sample, where the completion of preparatory courses organized by the Labor Office is required in order to receive the financial contribution. Nevertheless, most countries have installed mechanisms as incentives for their participants to profit from the nonfinancial support that is being offered, for example by distributing coaching vouchers or contributing financially to consulting services that have been used. An example of this practice can be found in France, which has implemented 
Table 1.2 Professional training versus education programs versus consulting/coaching

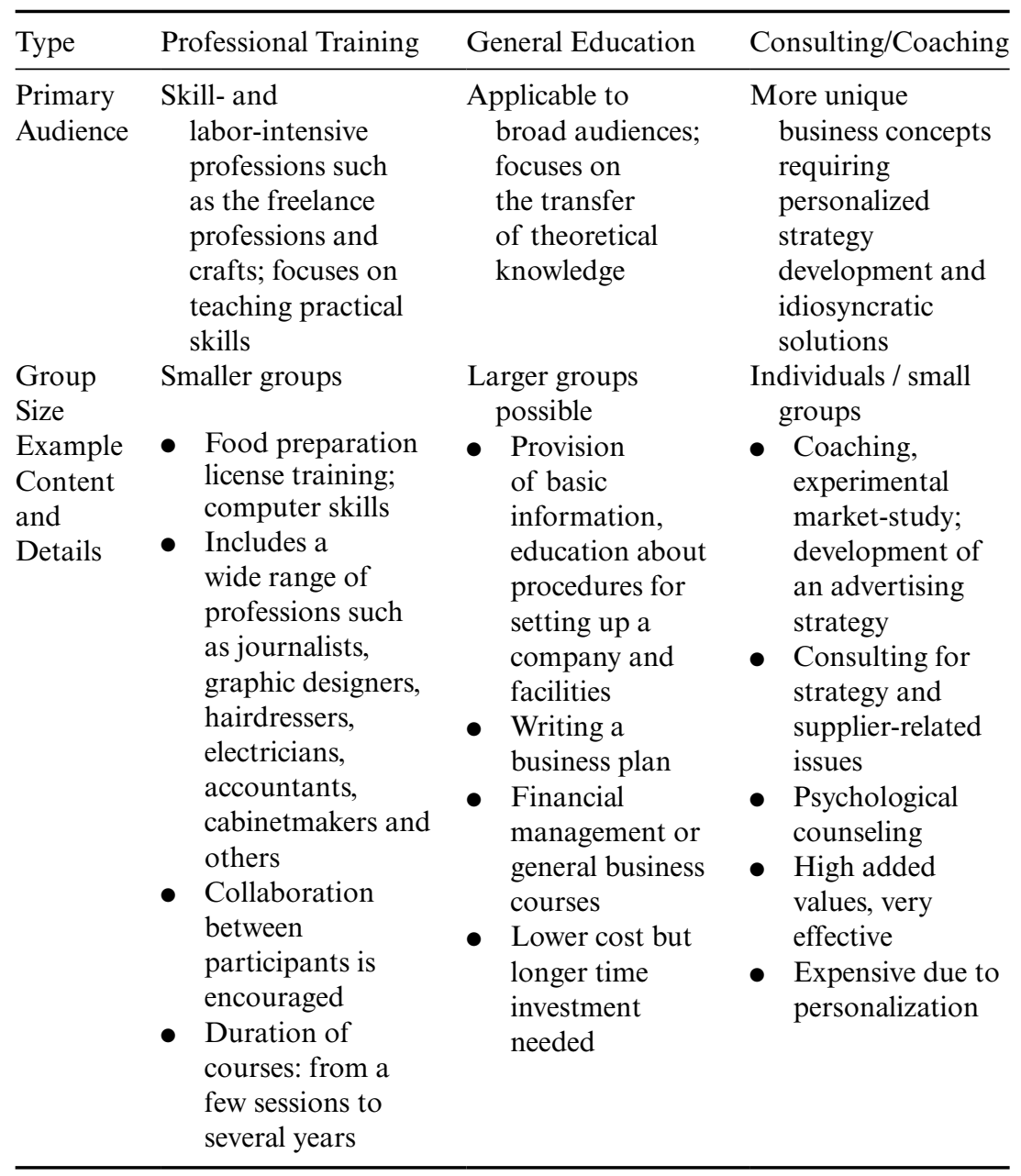

a consulting-voucher system within its ACCRE program. Participants receive a number of tickets that can be spent on counseling services at the beginning of the creation of the firm and during the following year (OECD, 2000). Authorities in the Netherlands offer to refund costs for coaching, courses or market surveys relating to the new business (Bekker, 2010). In Sweden, consultants who have been hired for business support services (for example, the evaluation of a business idea) can be paid by the 
authorities. The UK follows an indirect approach, granting an increase in the financial allowance in case the unemployed participates in some form of training. A number of prior studies have found that the publicity and visibility of support services appear to be strongly limited for the small and medium-sized companies (Thomas, 1994; Das Dores Guerreiro et al., 2000). This suggests that, in addition to the aforementioned incentives that have been put in place, policymakers may want to concentrate on making information about the various types of support more available to those seeking to start businesses.

\section{Governmental versus privatized provision of support}

While historically the majority of educational programs have been operated by governmental institutions, private contractors and Internet-based training programs have become more prominent in recent years (Nolan, 2003). For example, websites on the topic of business creation are being operated by government agencies in Germany, providing basic information about the most common questions surrounding new business creation. The regional employment offices supplement this central knowledge database as a provider of more personalized information available in the region, and by acting as hubs for connecting entrepreneurs with local contacts. Similar arrangements have been implemented by the Czech Republic, the Netherlands and Switzerland. The shift towards Internet-based support services is further strengthened through remote e-learning solutions to educate the unemployed on how to start and operate a business (for example, in the Czech Republic).

Several countries have partly or fully outsourced the business support of their program participants to private contractors (for example, Austria, Belgium and the Netherlands). This strategic move appears promising, as prior research indicates that the provision of business support services through private organizations will lead to greater success of the participating companies than services provided by government bodies (Kluve and Schmidt, 2002; Wössmann and Schütz, 2006) and that government-supported advisory services are less proficient at supporting firm growth, but rather at rescuing ailing firms (Bennett and Robson, 1999). Some of these services are offered free of charge for the participants, the duration is projected to last between six (Austria) to 18 months (Belgium).

Since positive outcomes of these services might not be immediately visible, it is especially vital to have a longer-term focus when evaluating the costs and benefits of business support services (Card, Kluve, and Weber, 2010); one source is citing a timeframe of three to four years as reasonable (Nolan, 2003). 
Table 1.3 Key program dimensions

\begin{tabular}{|c|c|c|c|}
\hline Program Structure & $\begin{array}{l}\text { Program } \\
\text { Eligibility }\end{array}$ & $\begin{array}{l}\text { Financial } \\
\text { Support }\end{array}$ & $\begin{array}{l}\text { Nonfinancial } \\
\text { Support }\end{array}$ \\
\hline $\begin{array}{l}\text { Centralized vs. } \\
\text { Decentralized } \\
\text { Structure }\end{array}$ & $\begin{array}{l}\text { Viability-check } \\
\text { of New Business } \\
\text { Concepts }\end{array}$ & Grants vs. Loans & $\begin{array}{l}\text { Training, } \\
\text { Consulting and } \\
\text { General Education }\end{array}$ \\
\hline \multirow{2}{*}{$\begin{array}{l}\text { Specific vs. General } \\
\text { Self-Employment } \\
\text { Promotion } \\
\text { Programs }\end{array}$} & $\begin{array}{l}\text { Influence of } \\
\text { Subjective } \\
\text { Assessment }\end{array}$ & $\begin{array}{l}\text { Single Payment } \\
\text { vs. Recurring } \\
\text { Payments }\end{array}$ & $\begin{array}{l}\text { Mandatory } \\
\text { vs. Voluntary } \\
\text { Participation }\end{array}$ \\
\hline & & $\begin{array}{l}\text { Provision of a } \\
\text { Fallback Solution }\end{array}$ & $\begin{array}{l}\text { Government } \\
\text { vs. Privatized } \\
\text { Organization }\end{array}$ \\
\hline
\end{tabular}

\section{Summary of Key Program Dimensions}

Building on these findings, Table 1.3 summarizes the key dimensions differentiating the policy schemes within the countries in this study: the program structure (centralized versus decentralized organization; specific versus general self-employment promotion programs), the program's eligibility requirements (objective versus subjective assessment; viability-check of the new business concept), practices related to the provision of financial support (grants versus loans; single versus recurring payments; provision of a fallback solution) as well as differences in the offering of nonfinancial business support services (types of business support, mandatory versus voluntary participation, public versus privatized provision of support services).

These dimensions reflect the major cornerstones of self-employment promotion programs for formerly unemployed individuals. Policymakers aiming at modifying existing programs or implementing new programs and those seeking to understand these policy initiatives can use these dimensions as a reference. Clearly, some factors are more important than others from both a governmental and a participant's perspective. Considerations regarding the program structure have a profound impact on the governmental resources that need to be devoted for the administration of the policy schemes. The choice of a centralized versus a decentralized structure needs to carefully balance specific advantages and disadvantages of the two approaches, and also needs to take into account a range of country-specific factors (for example, country size, population and existing policy infrastructure). The choice of operating a dedicated self-employment program 
for unemployed individuals as opposed to grouping them with others into a general self-employment promotion program needs to account for the difference between the unemployed and the non-unemployed founders with regards to the average level of education, skills and experience, which varies from country to country.

The nonfinancial support, on the other hand, is of greatest concern for those who create new businesses and need this type of support. Because business support services are characterized by a variety of private actors at the regional or local levels, they are oftentimes dissociated from centralized policymaking efforts, resulting in the apparent large heterogeneity across regions.

Other policy dimensions such as the strictness of eligibility and the level of financial support available to the program participants have a profound impact on both governments as well as participants. Choices related to these factors are much more flexible in the short and medium term compared to the structure and nonfinancial support, making these factors suitable levers for adapting active labor market strategies to changing political, economic and labor market circumstances. The impact and implications from the eligibility requirements and the available level of financial support from both a governmental as well as a participant perspective will be discussed in greater detail in the next section in order to shed light on the implications arising from these parameters.

\section{AN EXAMINATION OF CONTRASTING POLICY APPROACHES}

The previous section reveals how the policy schemes differ based on several criteria. While some practices are hardly comparable across the countries studied in this chapter and difficult to influence within policy revisions, two central parameters - the available level of financial support and the strictness of eligibility - are indicative of the general strategy followed by the government. These two dimensions not only define who is receiving how much financial support but also for how long. As both parameters are of particular interest to those affected by unemployment and wishing to become self-employed, these dimensions merit an in-depth discussion.

The first dimension describes the level of financial support, relating to both the amount and the duration of financial support that is being offered, as well as the type of financial support (grant versus loan). Several parameters that have been discussed in the section "Practices Related to the Provision of Financial Support" are grouped together in this dimension. The countries have been classified into low, medium or high levels 
of financial support. A "low level of financial support" corresponds to a period of less than six months of monetary support. Available support for a maximum duration between six to twelve months of financial support or a non-refundable single payment of an equal amount has been classified as "medium level of financial support," whereas any support lasting longer than one year or a one-time grant of similar size has been classified as "high levels of financial support." The second dimension indicates the strictness of eligibility for program participants. The countries have been classified as having either low or high eligibility requirements where countries classified as "low strictness" only demand the registration as unemployed in order to be eligible for funding, and countries listed as "high strictness" are imposing extended viability proofs (for example, assessing the business plan by a qualified institution, limiting the choice of industrial sector to those cases in which the applicant can document prior experience).

The classification of each country was made based on publicly available information about the programs, whereas unclear cases have been verified through interviews with employees of the national policy administration agencies. Figure 1.1 illustrates this categorization.

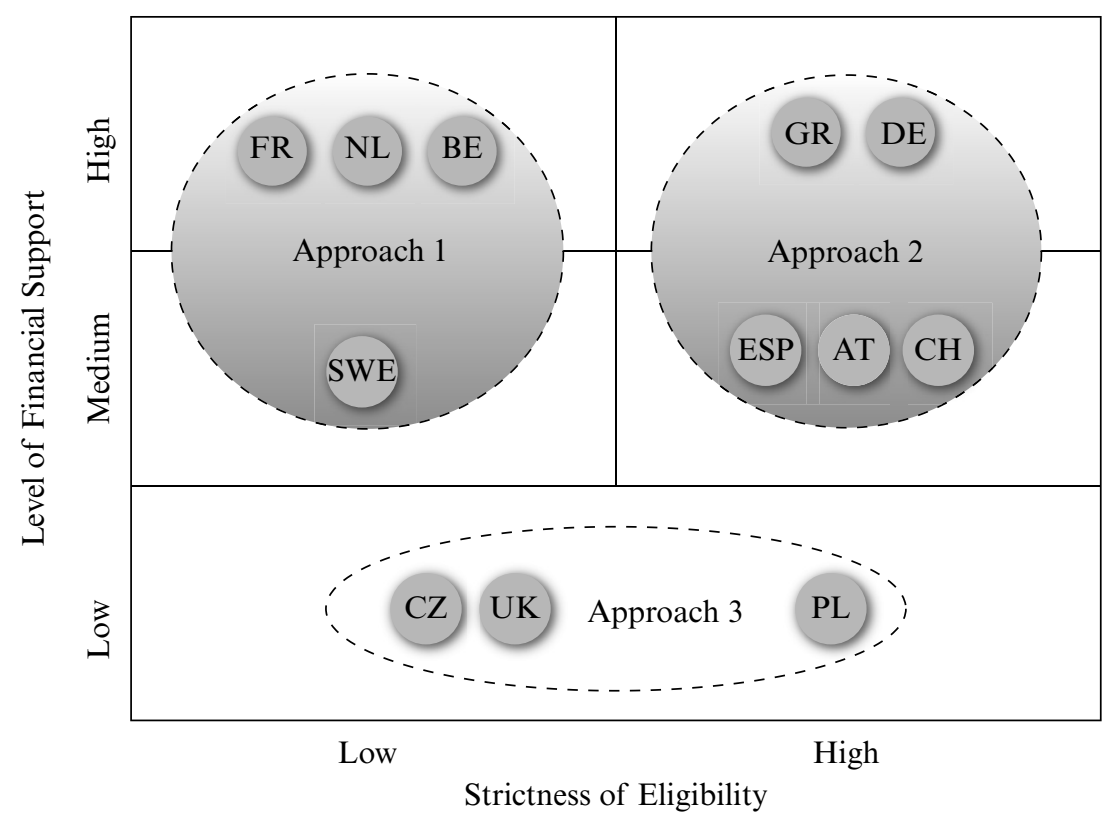

Figure 1.1 Assessment of programs based on financial support and strictness of eligibility 
By mapping the respective programs on these two dimensions, the different approaches of the countries in our sample become apparent. In order to better understand these contrasting approaches, several interviews with representatives from selected countries following the different approaches were conducted. In the following, we discuss the advantages and disadvantages of the strategic positioning for both governments and participants based on the previous overview of support schemes, supplemented by information gained during the interviews, as well as corresponding publicly available information.

\section{Differing Policy Approaches}

\section{Approach 1: Low strictness of eligibility/medium to high levels of financial support}

Countries positioned in the top left corner of the categorization feature a rather generous policy scheme as almost anyone is granted the comparatively high financial support when engaging in an entrepreneurial activity. France represents an example for this type of policy orientation.

From a governmental perspective, granting large shares of the unemployed population financial support when engaging in entrepreneurship represents a relatively expensive approach, as even ideas with lower probabilities of success are supported. In France, for instance, more than 50 percent of all companies are started with the financial support from this government program (APCE, 2012). Although the current policy has been found to result in high survival rates during the support period, anecdotal evidence suggests that many problems only become visible after the financial subsidies are terminated. The governmental support thus appears to incite a false sense of economic security among the participants, as a disciplined strategy development and implementation process is not sufficiently encouraged from the beginning. Quantitative data from the year 2011 indicates that more than 80 percent of companies supported by the program in France are single-founder businesses, whereas around 80 percent of companies are service or commerce-related businesses (APCE, 2012). Correspondingly, such an inclusive program might have a limited impact in terms of national economic growth, demanding for differentiated measures of success that are able to capture the societal impact of this policy strategy.

From a participant perspective, such policy schemes are received rather positively, as the broader population of unemployed individuals has the possibility to explore entrepreneurship as a viable career path, and ideas with an extended exploratory phase - prior to knowing about the financial viability — can receive monetary support for an extended period. In this 
case, the participants are somewhat protected from too much pressure to identify a viable business model that would be present without the policy scheme. However, anecdotal evidence suggests that such unrestrained programs specifically targeted towards unemployed people can result in a substantial social divide, as the formal unemployment registration is required to be eligible for funding. Those starting a business while employed elsewhere thus tend to perceive such policies as somewhat unfair and unjust.

\section{Approach 2: High strictness of eligibility/high level of financial support}

The top right corner of the categorization indicates programs that can be characterized as generous, yet highly selective. One example of a country within this category is Germany.

From a government perspective, having strict eligibility criteria while simultaneously offering generous financial support leads to an increased selection effort during the early stage of the process. The focus of this approach is on those participants that have the highest probability of succeeding. According to the German employment ministry, this positioning is the result of a recent strategic shift towards an increased emphasis of re-employment of unemployed individuals rather than self-employment stemming from the currently (2013) optimistic economic situation in the country. As a consequence, the accessibility of these programs has been changed from being generally available for every unemployed person interested in becoming self-employed, to being a merely voluntary offering at the discretion of the respective employment agency. While supporting only the most capable citizens in becoming entrepreneurs might increase the life chances of such firms, this strategy denies large shares of the population the chance to explore whether self-employment represents a viable career for them.

From a participant perspective, this strategic shift has both positive and negative aspects. Those allowed into the program are likely to possess alternative employment options, whereas those denied might lack such options, thus potentially excluding some people from being able to participate in the labor market. Assuming a functioning selection process, the positive aspects of such a policy variant reside in the quick market feedback to the individuals, indicating whether their business ideas are economically feasible of having long-term survival prospects in the market.

\section{Approach 3: Low level of financial support}

The lower part of the categorization indicates programs featuring only a low level of financial support, thus reducing the importance of the eligibility requirements in this approach. Poland and the Czech Republic are examples of countries following this policy strategy in our study. 
While government expenditures related to the provision of financial support are kept at a minimum in such a policy variant, only marginal positive externalities with respect to reducing unemployment and generating economic growth can be expected in return. New businesses have to find alternative ways to compensate their need for funding through other actors such as financial institutions and private investors, which might be an even more difficult endeavor for unemployed individuals compared to others who did not suffer from an unemployment spell.

From a participant perspective, this approach is similar to a total lack of support, as the restricted financial support is likely to be insufficient for the exploitation of most opportunities, increasing the chance of establishing under-resourced businesses with poor survival chances from the onset (ILO, 2002). Only business concepts requiring a minimal amount of financing, such as simple arbitrage or services businesses, can be exploited in case additional private funds are absent. The implementation of more complex, larger-scale business ideas is thus reserved to those having access to other capital sources in this policy approach. On a more positive note, the mere existence of a dedicated entrepreneurship support policy targeted at unemployed people is likely to entice at least some individuals to try out if self-employment presents a viable career option for them. Although we can only speculate about the impact of such a policy approach, participants lacking additional sources of financing might feel discouraged at a later point in time when having to realize that the available funding proves insufficient for the realization of many projects.

\section{Key Insights}

The categorization of countries provides a snapshot of the status quo of the pan-European policy landscape designed to help unemployed individuals transition into self-employment within a number of European countries. While this landscape can be expected to continue evolving in the years to come, several insights can be distilled from the current examination:

- Two central parameters, the level of financial support and the strictness of eligibility of the respective national policies, reveal several contrasting policy approaches with differing implications from both a governmental and a participant perspective.

- While some programs have a strategy of primarily promoting growth-oriented entrepreneurship, others follow a rather inclusive labor market approach, perceiving entrepreneurship as a potentially viable career option for larger shares of the population and as a 
solution to increased rates of unemployment. Again others offer only very limited assistance for those seeking to create a business after a period of unemployment, revealing that entrepreneurship support policies are not a top policy priority. Correspondingly, the programs cannot be ranked in order of effectiveness or efficiency, as each policy scheme follows an approach that has been adapted to the specific national context, shaped by both economic and societal factors (Staber and Bögenhold, 1993).

- Even generous policies can have a negative impact on participants, as they might incite a false sense of economic security as indicated by the example of France. Survival rates during the support period would thus be artificially inflated but can be expected to drop sharply after the funding expires. Future studies are needed to improve our understanding if this effect is visible in larger-scale empirical research and identified in other countries as well.

\section{CONCLUSION}

This chapter provides an international comparative analysis of the policy initiatives designed to help those affected by unemployment transition into self-employment within a number of European countries. Following an overview of the history of the programs as well as a comparative analysis of currently existing programs across Europe, we identified and analyzed key program dimensions, including the overall program structure, the program eligibility requirements, and practices related to the provision of financial support and nonfinancial business support services. This analysis revealed several distinctive features about the current state of development of these policies:

- The program structure follows a centralized approach in the majority of countries with consistent national policy schemes that are being executed by regional employment agencies. Both dedicated, and generic self-employment support programs can be found.

- Most countries have introduced some sort of eligibility requirements that the applicants need to fulfill in order to receive the financial support including a well-refined business concept that needs to be approved by a qualified institution. As the criteria often leave room for interpretation by labor office employees, the assessments are likely to be influenced by subjective factors, resulting in potential regional differences of how the national policies are being implemented. 
- While some form of financial support for the program participants, either direct or indirect, is available in all of the investigated countries, the type, amount and duration of monetary support differs widely. However, we could identify grant-based monthly contributions for half a year to a year being the most common approach. A basic fallback solution in case the entrepreneurial endeavor proves unsuccessful is available in all of the countries.

- The available business support services differ markedly across the countries, but also across different regions within the same country. One area for further policy development could focus on making information about the various types of support more transparentan observation that is in line with prior research indicating that the publicity and visibility of support services is strongly limited for small and medium-sized companies (Thomas, 1994; Das Dores Guerreiro et al., 2000). Prior studies moreover suggest, that private organizations have advantages over government bodies in the provision of business support services (Kluve and Schmidt, 2002; Wössmann and Schütz, 2006) and that government-supported advisory services might be less proficient at supporting firm growth but instead better in rescuing ailing firms compared to services offered by the private sector (Bennett and Robson, 1999). Governmental interventions regarding business support services thus need to be carefully planned and potentially limited to market failures in the provision of support by the private sector.

- The program eligibility requirements and the level of financial support are central parameters revealing several contrasting policy approaches. Some policies primarily aim at promoting growthoriented entrepreneurship, whereas others see entrepreneurship as a potentially viable option for larger shares of the population and as a solution to increased rates of unemployment. As prior studies have indicated that the costs of these programs are considerably lower than those of other ALMPs or the continued provision of unemployment benefits (OECD, 2000), the strategy of making entrepreneurship part of the solution towards reducing unemployment in many developed countries appears to be promising. Such policies can be an important instrument for generating positive economic and social externalities also in geographical areas where similar initiatives have thus far been scant or even absent. However, approaches offering only limited assistance for those seeking to create a business after a period of unemployment can also be appropriate in some contexts. A rank-ordering of program designs in terms of their general superiority is thus not feasible. 


\section{Outlook and Future Research}

Despite an improved understanding of the structure and outcomes of the analyzed policy programs designed to help unemployed individuals transition into self-employment, further research is needed that can shed light on a number of issues:

- Need for quantitative analyses: We identified a need for additional international comparison studies that evaluate the programs in terms of their effectiveness and efficiency. Unanswered questions include: How can dedicated self-employment policies targeted at formerly unemployed individuals be compared quantitatively to generic programs open to anyone interested in starting a business? How might the eligibility requirements and the level of financial support be altered depending on the current economic circumstances and depending on the type of firm that is to be founded? What type of business support services can be provided in a cost-efficient manner by governments as well as private organizations? Inquiring into these topics can provide decision-makers with more quantifiable information in the future than what was available at the time of this study.

- Need for additional performance measures: To date, the central performance indicator of the programs has been the survival rate of firms supported by the programs. However, due to selection effects, the survival rates are not directly comparable as a result of the differing eligibility criteria. Policies featuring strict selection criteria thus are likely to lead to higher survival rates, as only the most capable individuals were previously admitted to the program. In case the policy schemes focus on increasing the country's economic output, the growth of the newly created businesses, measured for example in terms of tax revenue or by the creation of new jobs, should also be monitored and taken into account as a meaningful performance indicator. In case the policy schemes are part of the national social development strategies, the impact resulting from eligibility requirements needs to be more seriously considered in order to help a large proportion of those affected by unemployment discover whether self-employment represents a potentially viable career path for them. Measures such as levels of resulting work- and life-satisfaction might be valuable additions for these policy approaches. Programs aiming to pursue both goals simultaneously could benefit from more insights into the quantitative trade-offs of the different policy strategies outlined in the section "An Examination of Contrasting Policy Approaches." 
- Need for effective communication mechanisms: While self-employment has the potential to be a rewarding professional career path, the reality that self-employment is also risky should not be neglected. A critical element for the successful implementation of functional programs thus represents an honest and authentic communication with prospective participants, rather than promoting self-employment as a viable path for everyone (Kellard and Middleton, 1998). Future research could help investigate the different mechanisms by which the government is able to communicate this reality to the prospective applicants.

- Need for better understanding of support services: There are several questions surrounding the provision of nonfinancial support services deserving further attention: Which type of business support is the most cost-effective from a government perspective? How can governmental agencies ensure that appropriate business support services are widely available? Which services are best provided privately, versus publicly administered and controlled? How can business support services be made more accessible to those interested in starting a business, including those located outside of metropolitan areas?

While more research is needed in order to shed light on these and other questions, the comparative analysis presented in this chapter was able to uncover several interesting facts about the current stage of development of policies designed to support the transition of formerly unemployed individuals to self-employment. Our work contributes to an improved understanding and a heightened awareness of the public policy schemes that were previously difficult to compare, facilitating the exchange of bestpractice solutions in order to improve existing programs and in developing new programs. The programs have the potential to stimulate a number of positive secondary effects, such as a relief of the welfare system, increased societal well-being, and economic growth. It should not be forgotten, however, that such policy initiatives are only one tool within a larger set of active labor market policies, albeit an important one deserving further attention as acknowledged within the current "Europe 2020 Strategy" (European Commission, 2010). It is hoped that the increased transparency that this chapter created continues to stimulate the international dialogue on this topic.

\section{ACKNOWLEDGEMENTS}

This chapter would not have been possible without the generous support and help of a number of people. We would thus like to express our 
gratitude to those who have supported this study through their time and knowledge. First, we would like to thank Professor Marc Gruber and Professor John Dencker for their valuable insights and comments on the content, structure and contribution of this chapter. Second, we would like to thank those who have participated in the interviews that helped us improve our understanding of the specifics of the government programs. Specifically, we would like to thank Dietrich Englert from the German "Bundesamt für Arbeit und Soziales," Laurent Deloisen from the French Pôle-Emploi (Pays de la Loire), Martina Jakl from the Swiss-Czech TechTransfer Office and Lech Antkowiak from the Polish Department of Labor in Warsaw. Additionally, we want to thank David Halabisky and Paul Swaim from the OECD for providing valuable insights about existing analyses of policy schemes on a pan-European level, Víctor Martíni-Sánchez and Argyro Nikiforou for having helped us gather information for Spain and Greece, respectively.

\section{NOTE}

1. The traditionally employed elements of ALMP comprised public employment services, subsidized employment within the private sector and labor market training programs, however all but the latter have been evaluated rather unenthusiastically in subsequent analyses (Heckman, Lalonde, and Smith, 1999; Martin and Grubb, 2001; Kluve and Schmidt, 2002; Boone and van Ours, 2004).

\section{REFERENCES}

APCE (2012, April). La Création D’Entreprises en France en 2011. L'Agence Pour la Création d'Entreprises. Paris.

Baumgartner, H.J., and Caliendo, M. (2008). Turning unemployment into selfemployment: effectiveness of two start-up programmes. Oxford Bulletin of Economics and Statistics, 70(3), 347-373.

Bekker, S. (2010). European Employment Observatory, EEO Review: Selfemployment, Netherlands. Birmingham.

Bennett, J.R., and Robson, P.J.A. (1999). The use of external business advice by SMEs in Britain. Entrepreneurship and Regional Development, (11), 155-180.

Benus, J.M. (fall 1994). Self-employment programs: a new reemployment strategy. Entrepreneurship Theory and Practice, 19(2), 73-86.

Blanchflower, D., and Oswald, A.J. (1990). What makes an Entrepreneur? Evidence on Inheritance and Capital Constraints. Cambridge, MA: National Bureau of Economic Research.

Block, J., and Sandner, P. (2006). The effect of motivation on self-employment duration in Germany: necessity versus opportunity entrepreneurs. MPRA Paper series, no. 215. Munich. 
Block, J., and Wagner, M. (2010). Necessity and opportunity entrepreneurs in Germany: characteristics and earnings differentials. Schmalenbach Business Review, 62(4), 154-174.

Boone, J., and van Ours, J.C. (2004). Effective active labor market policies. IZA Discussion Paper series, no. 1335. Retrieved on February 16, 2016 from http:// hdl.handle.net/10419/20604.

Bosma, N., Acs, Z.J., Autio, E., Coduras, A., and Levie, J. (2008). Global Entrepreneurship Monitor, 2008 Executive Report. Babson Park, MA: Babson College.

Brüderl, J., and Preisendörfer, P. (1998). Network support and the success of newly founded business. Small Business Economics, 10(3), 213-225.

Bundesagentur für Arbeit (2012). Aufbau und Organisation. Retrieved on February 15, 2013 from http://www.arbeitsagentur.de/nn_27200/Navigation/ zentral/Servicebereich/Ueber-Uns/Aufbau-und-Organisation/Aufbau-undOrganisation-Nav.html.

Caliendo, M., and Kritikos, A. (2009). I want to, but I also need to: start-ups resulting from opportunity and necessity. IZA Discussion Paper series, no. 4661.

Caliendo, M., and Künn, S. (2011). Start-up subsidies for the unemployed: longterm evidence and effect heterogeneity. Journal of Public Economics, 95(3), 311-331.

Card, D., Kluve, J., and Weber, A. (2010). Active labour market policy evaluations: a meta-analysis. The Economic Journal, Wiley Online Library.

Carling, K., and Gustafson, L. (1999). Self-employment vs. subsidized employment: is there a difference in the re-unemployment risk? Institute for Labour Market Policy Evaluation (IFAU), Working Paper.

Corral, A., Isusi, I., and Stack, J. (2006). Support Measures for Business Creation Following Restructuring. Dublin, Ireland: European Foundation for the Improvement of Living and Working Conditions.

Cueto, B., and Mato, J. (2006). An analysis of self-employment subsidies with duration models. Applied Economics, (38), 23-32.

Das Dores Guerreiro, M., Palma, S., Pegado, E., and Rodrigues, N. (2000, August). Relações Sócio-Laborais em Micro e Pequenas Empresas (Occupational and social relations in the micro and small enterprises). OEFP. Lisbon.

Dencker, J.C., Gruber, M., and Shah, S.K. (2009a). Pre-entry knowledge, learning, and the survival of new firms. Organization Science, 20(3), 516-537.

Dencker, J.C., Gruber, M., and Shah, S.K. (2009b). Individual and opportunity factors influencing job creation in new firms. Academy of Management Journal, $52(6), 1125-1147$.

Désiage, L., Duhautois, R., and Redor, D. (2010). Do public subsidies have an impact on new firm survival? An empirical study with French data. TEPP Working Paper, no. 2010-4. ISSN 2110-5472.

Duggan, C. (1998). Self-employment in the United Kingdom and Ireland. Current trends, policies and programmes. Paper presented at the OECD Conference on self-employment, Burlington, September 24-26, 1998.

European Commission (1997). The Way Forward: The European Employment Strategy. DG V, Luxembourg: Office for Official Publications of the European Communities. Brussels.

European Commission (2010). Europe 2020: A Strategy for Smart, Sustainable and Inclusive Growth. Retrieved on January 15, 2013 from http://ec.europa.eu/ europe2020/index_en.htm. 
Fritsch, M. (2008). How does new business development affect regional development? Introduction to the Special Issue, Small Business Economics, (30), 1-14.

Guérin, I., and Vallat, D. (2000). Les clefs du succès de la création d'entreprise par des chomeurs. A contribution to the International Labour Organization (ILO) Action Programme: Enterprise Creation by the Unemployed-Microfinance in Industrialized Countries. Centre Walras, France.

Heckman, J., Lalonde, R., and Smith, J. (1999). The economics and econometrics of active labor market programs. In: O.C. Ashenfelter and D. Card (eds), Handbook of Labor Economics, Elsevier, 3, 1865-2097.

IAB Kurzbericht (2007). Ausgabe 10, April 10, 2007: Existenzgründungen: Unterm Strich ein Erfolg. Bundesagentur für Arbeit. Nürnberg.

International Labor Organization (ILO) (2002). Micro-finance in Industrialized Countries: Helping the Unemployed to Start a Business. Geneva: ILO.

Jakobsen, L., and Ellegaard, C.E. (2012). Danish Technological Institute. Public measures to support self-employment and job creation in one-person and micro enterprises. Report. European Foundation for the Improvement of Living and Working Conditions.

Kellard, K., and Middleton, S. (1998). Helping unemployed people into selfemployment. Research Brief no. 46. Centre for Research in Social Policy. Department for Education and Employment. Leicestershire, UK.

Kluve, J., and Schmidt, C.M. (2002). Can training and employment subsidies combat European unemployment? Economic Policy, (35), 411-448.

Martin, J., and Grubb, D. (2001). What works and for whom: a review of OECD countries' experiences with active labour market policies. Swedish Economic Policy Review, 8(2), 9-56.

Meager, N. (1996). From unemployment to self-employment: labour market policies for business start-up. In G. Schmidt, J. O'Reilly, and K. Schömann (eds), International Handbook of Labour Market Policy and Evaluation (Chapter 16). Cheltenham, UK and Northampton, MA, USA: Edward Elgar Publishing.

Meager, N., Bates, P., and Cowling, M. (2003). An evaluation of business start-up support for young people. National Institute Economic Review, (186), 59-72.

Metcalf, H. (1998). Self-Employment for the Unemployed: The Role of Public Policy. Department of Education and Employment, Research Report RR47.

Nolan, A. (2003). Entrepreneurship and Local Economic Development: Policy Innovations in Industrialized Countries. Paris: Organisation for Economic Cooperation and Development.

O'Leary, C.J. (1999). Promoting self employment among the unemployed in Hungary and Poland. Working Paper. W.E. Upjohn Institute for Employment Research.

Organisation for Economic Co-operation and Development (OECD). (1992). Recent developments in self-employment. In Recent Developments in Selfemployment (Chapter 4). Paris: OECD.

Organisation for Economic Co-operation and Development (OECD). (2000). The partial renaissance of self-employment. In Employment Outlook (Chapter 5). Paris: OECD.

Parker, S.C. (2004). The Economics of Self-employment and Entrepreneurship. Cambridge, UK: Cambridge University Press.

Pfeiffer, F., and Reize, F. (2000). Business start-ups by the unemployed-an econometric analysis based on firm data. Labour Economics, 7(5), 629-663.

Rodríguez-Planas, N. (2008). Understanding why public employment services 
and small-business assistance programs work at getting the unemployed back to work: evidence from Romania. Universitat Autònoma de Barcelona, IZA and FEDEA.

Rodríguez-Planas, N. (2010). Channels through which public employment services and small business assistance programmes work. Oxford Bulletin of Economics and Statistics, 72(4), 458-485.

Shane, S. (2003). A General Theory of Entrepreneurship: The Individual-Opportunity Nexus. New Horizons in Entrepreneurship Series. Cheltenham, UK and Northampton, MA, USA: Edward Elgar Publishing.

Sheikh, S., Pecher, I., Steiber, N., and Heck1, E. (2002). Support Services for Micro, Small and Sole Proprietor's Businesses: Final report. Vienna: Austrian Institute for Small Business Research (IFGH), and European Network for SME Research (ENSR).

Staber, U., and Bögenhold, D. (1993). Self-employment: a study of seventeen OECD countries. Industrial Relations Journal, 24(2), 126-137.

Statistics Sweden (1998). New Started Enterprises in Sweden 1996 and 1997. Statistika meddelanden, SCB, Örebro.

Storey, D. (1994). Understanding the Small Business Sector. London: Routledge.

Thomas, K.-G. (1994). Die mittelständische Unternehmung im Entwicklungsprozess (SMEs in their development process). Schriftenreihe Wirtschafts- und Sozialwissenschaften, Bd.19. Ludwigsburg, Berlin.

Van Es, F. and Van Vuuren, D.J. (2011). A decomposition of the growth in selfemployment. Applied Economics Letters, 18(17), 1665-1669.

Veverková, S. (2012). ERM comparative analytical report on public support instruments to support self-employment and job creation in one-person and micro enterprises. EMCC/Research Institute for Labour and Social Affairs.

Wössmann, L., and Schütz, G. (2006). Efficiency and equity in European education and training systems. European Expert Network on Economics of Education (EENEE). Analytical Report for the European Commission. 